\title{
Co-creating a Digital Service Concept in Wellbeing for the Elderly
}

\author{
By Leena Alakoski* \\ Irma Tikkanen ${ }^{\dagger}$ \\ Sari Jääskeläinen
}

\begin{abstract}
The aim of this paper is to describe, how a digital service concept in wellbeing for the elderly was co-created as a process and a content in higher education. The theoretical framework comprises constructivism and the Learning by Developing action model. Existing research on social service innovations; the Internet, the elderly and digital services; and co-creation with the elderly is illustrated. Furthermore, co-creation of the digital service concept in wellbeing is evaluated by the students from the viewpoints of learning and competence development. The project results indicated that the co-created digital service concept in wellbeing includes following information concerning the service providers and provided services for the elderly: services, products, activities, general information, information for carers and firms, and links to the local and public organisations. The co-creation process was composed of seven phases. The students received real-life experience when working in a multidisciplinary team with various opinions, competences, and theoretical backgrounds. The results illustrate an example concerning how the internationally awarded digital service concept in wellbeing was co-created by a student team, teachers, and the elderly within the curriculum from the viewpoint of constructivism.
\end{abstract}

Keywords: Co-creation, Constructivism, Elderly, Service concept, Students

\section{Introduction}

The population in Finland is ageing rapidly. In 2013, the number of people who were older than 65 years amounted to $19.4 \%$ in Finland, and in the City of Espoo the percentage was 13.2 (Statistics Finland 2015). In the City of Espoo, the number of people older than 65 years in 2015 is expected to be 35,909 and by the year 2025 the equivalent estimate comprises 47,522 individuals (The Helsinki Metropolitan Area Advisory Board 2007). The Internet connectivity in Finland is high, e.g. the share of people older than 65 years using Internet many times a day is $49 \%$ (Statistics Finland 2016). Hence, more attention has to be paid to proper services provided for the elderly. However, the financial resources of the City of Espoo are limited. That is why all kinds of private services provided for the elderly are welcome in order to support their wellbeing at home. Furthermore, because the City of Espoo is rather small, it is challenging to find service providers and their services.

Wellbeing is based on independence and high quality of living in the familiar and safe home environment also at an older age. Good mental and physical health, functional ability, balanced nutrition and a social life form the daily life challenges of ageing people (Lehto and Leskelä 2011). The national policy in Finland

\footnotetext{
* Principal Lecturer, Laurea University of Applied Sciences, Finland.

${ }^{\dagger}$ Docent, University of Eastern Finland, Finland.

* Senior Lecturer, Laurea University of Applied Sciences, Finland.
} 
stipulates that municipalities are responsible for taking care of the elderly who cannot survive at homes independently. Therefore, municipal services should be provided for them at home, including e.g. home care catering services (Tikkanen and Silvan 2012) as well as health services (measuring blood pressure; delivering medicines; and hygiene services). Because the number of ageing people is increasing, more public services have to be provided. For the elderly, who are able to buy private services, the channels and communication concerning the provided services have to be created.

\section{Description of the InnoEspoo Project}

The InnoEspoo project was established in 2013 and it is managed by InnoOmnia, a lifelong learning and entrepreneurial hub. The InnoEspoo project is building an expert network where the members include the following parties: the City of Espoo; entrepreneurs located in the City of Espoo; Omnia Vocational College; the Laurea University of Applied Sciences; and Aalto University's Small Business Center and their teachers, students, and developers (Espoo 2015). Services to be developed in the InnoEspoo project support the expertise of the small firms and strengthen their business activities, student entrepreneurship, and the development of innovative services in the City of Espoo. The focus is to increase entrepreneurship from the viewpoint of sustainable wellbeing. The actors in the expert network are especially micro firms, part-time entrepreneurs, student-based ventures and cooperatives. The InnoEspoo project will complement other business services and education offered in the region and thus bring value added for the entrepreneurs and the students with pedagogical methods and community training (Espoo 2015).

The wellbeing digital service seniori365.fi is a part of the InnoEspoo project. It is implemented by the Laurea University of Applied Sciences, Aalto University's Small Business Center, and Omnia Vocational College (Aalto University 2015) ${ }^{1}$. The target groups comprise the elderly in the City of Espoo and their relatives aiming to support wellbeing for the elderly at home. The project was financed by the European Social Fund (ESF), the Centre for Economic Development, Transport and the Environment in Uusimaa, and the City of Espoo (Lyytikäinen and Niskala 2015).

\section{The Literature Review}

\section{Constructivism and the Learning by Developing Action Model}

Constructivism was divided by Porcaro (2011) into cognitive constructivism and socio-cultural constructivism. A conceptual model proposed by Porcaro (2011) includes the innovations or pedagogical methods and learning environments located at the intersection of teachers' and students' educational

\footnotetext{
${ }^{1}$ InnoEspoossa developed a digital service www.seniori365.fi elected to Good Practice 2014 Service Innovation. Retrieved from goo.gl/0EPEmR.
} 
philosophies and institutional systems also including the national context. With respect to learning, constructive learning includes four aspects as follows: learners construct their own meaning; new learning builds on prior knowledge; learning is enhanced by social interaction; and finally, meaningful learning develops through "authentic" tasks in constructive learning (Cooperstein and Kocevar-Weidinger 2004, Good and Brophy 1994, Tikkanen and Vakkuri 2013).

Nuthall (2002) defined the social constructivist model of teaching including pedagogical intentions so that it focuses on the need to bring about intellectually significant changes in the minds of students through their social process. The content and processes of the mind reflect the cultural and social contexts where they are being developed. Soma and Reynold's (2014) study indicated that considering the learning objectives of a cross-cultural context are of paramount importance when engaging in cross-cultural management curriculum and teaching design. Such social contexts, although they are complex and challenging, often form a perfect opportunity where cross-cultural competence can be developed. Brown (2006) concluded that institutions should move away from providing content per se to learners. Instead, it is necessary to enable learners to identify, manipulate and evaluate information and knowledge and to integrate this knowledge into their world of work and life. Further aspects include solving problems and communicating this knowledge to others.

The Learning by Developing (LbD) action model is based on constructivism. At the Laurea University of Applied Sciences, Finland, a pedagogical model of $\mathrm{LbD}$ is developed and applied. The basis for the development-based learning is a real life development project regenerating practice. Its implementation requires cooperation between teachers, students and work life partners, and optimally new knowledge and competences are produced (Kallioinen 2008: 7). The LbD action model includes five main stages (Figure 1) as follows: creativity, authenticity, partnership, experiencing, and research orientation. Each main stage includes complementary stages, and the total number of complementary stages is ten. The core of the LbD action model consists of individual learning, community learning, and producing new competence (Raij 2014).

In the LbD action model, the students are able to participate already at the beginning of their studies in an innovation system linked to various kinds of development projects. Learning is facilitated by experience and professional growth from the beginning and thus contributes to emerging structures based on experience (Kallioinen 2008: 7). 
Figure 1. Recognised Stages of the LbD Action Model that Steer Implementation

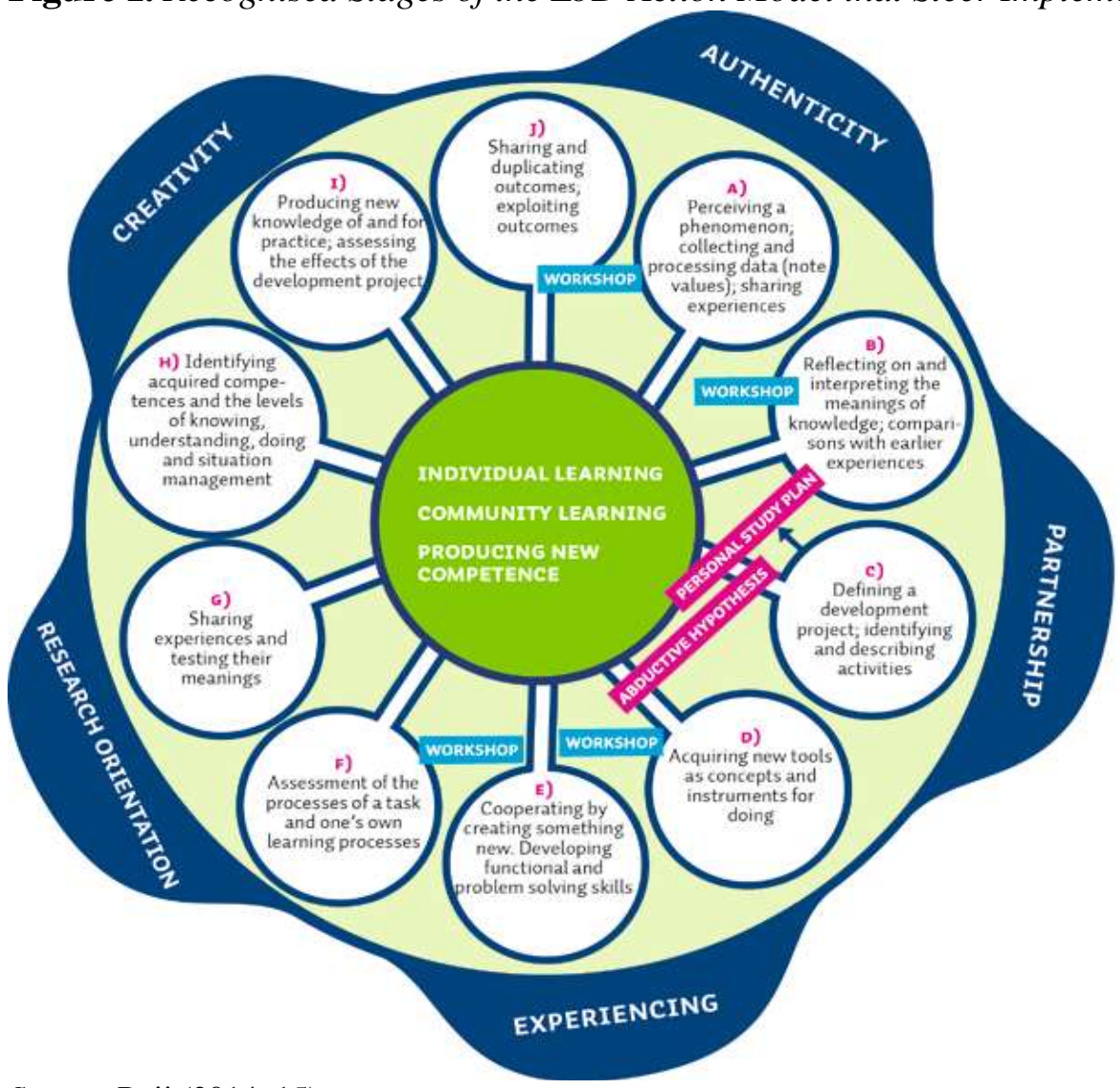

Source: Raij (2014: 15).

According to the Act on Universities of Applied Sciences (14.11.2014/ 932), one of the three main tasks for a university of applied sciences consists of regional development. The student participates in regional development by developing one activity or a task in a chosen organisation included in a Bachelor's thesis or other learning tasks. Moreover, the development problem is based on an authentic development task and its relevant solution utilizing existing knowledge. When developing a solution to the problem, knowledge and information are needed concerning the business activities of the chosen organisation. Moreover, also information is required related to the industry and competitors and their operational methods, as well as technological development and megatrends related to the topic etc. However, at the core of the problem there are the customers of the organisation, both business-to-business customers and consumers, their needs, goals, problems, and experiences. This kind of knowledge and information requires empirical data and analysis as well as applying different kinds of research and development methods and tools.

\footnotetext{
${ }^{2}$ Act on Universities of Applied Sciences 14.11.2014/932 (in Finnish). Retrieved from goo.gl/ z7JHJ3.
} 


\section{Existing Research on Social Service Innovation in Brief}

Service innovations and social innovations have been explored from multiple viewpoints. Wang et al. (2015) researched the different modes of service innovations focusing on both product and process innovation. A typology was presented indicating that all of the business model innovations involve external partnerships during the development process. Hsieh et al. (2013) linked academic classifications of service innovation with practical activities by firms to detail the essence of service innovation by showing that elements of service innovations vary depending on the company size, service innovation experience and industry life cycle. Giannopoulou et al. (2014) explored the capabilities for reinforcing creativity in service innovations from a practice-based perspective. As for the findings, seven relevant capabilities were proposed.

Duncan and Breslin (2009) described a program for translating patient needs into health service innovations. The findings indicated that health service organisations needed to pay more attention to the patient experience in order to meet patient needs. Hennala et al.'s (2011) study presented a case of facilitating innovations by involving stakeholder groups when developing service production in the public sector. Based on the findings, it was suggested that an open innovation model and particularly the inclusion of external information and knowledge from potential service users generated new insights and added to the value of the development process.

European Commission (2015) promotes social innovations by funding social innovation community, a network of networks. Finland has focused its social innovations on health and welfare field. An example of the Finnish social innovations is provided by HyvinvointiTV (WellbeingTV 2015) ${ }^{3}$. Other examples of social innovation projects in other European countries comprise Passion for Life (SSIA 2015) in Sweden; Abitare Solidare (UniCredit Foundation 2015) in Italy; and Age no Barrier (UniCredit Foundation 2015) in United Kingdom. Moreover, INNOVAGE (2014) project has published the guidelines on involving older people in social innovation development. The project received funding from European Union.

Nylén and Holmström (2015) identified five key areas to be measured and evaluated in seeking to manage digital products and service innovations as follows: user experience; value proposition; digital evolution scanning; new skills; and time for improvisation. User experience can be measured by its levels of usability, aesthetics, and engagement. Value proposition answers how they create value for the users. Digital evolution scanning involves gathering intelligence on new devices. With respect to new skills, firms have to acquire new skills both internally and externally while establishing digital roles. Time for improvisation requires space, time and coordination.

\footnotetext{
${ }^{3}$ WellbeingTV - HyvinvointiTV (2015). Retrieved from goo.gl/z4yddA.
} 


\section{Internet, Elderly and Digital Services}

The existing research on digital services for the elderly on the Internet has focused its themes from the viewpoints of needs, usage, choice, and access. Vuori and Holmlund-Rytkönen (2005) explored the Internet-related needs and wants of the elderly and identified Internet user segments. Trocchia and Janda (2000) investigated Internet usage among aged individuals. Eastman and Iyer (2004) researched the use of the Internet by a national random survey of the elderly consumers and the impact of attitudes, innovations, and demographics with respect to their use. Hill et al. (2008) investigated the phenomenon of Internet engagement amongst elderly people. Reisenwitz et al. (2007) examined how mature consumers' use of the Internet is impacted by their proneness to nostalgia, innovativeness and risk aversion. Tatnall and Lepa's (2003) study focused on the Internet, e-commerce and the elderly from the viewpoint of an actor-network approach to researching reasons for adoption and use. Helsper (2009) explored the ageing on the Internet from the viewpoint of digital choices and exclusion among the elderly. Blake (1998) investigated Internet access for ageing people.

From the viewpoint of services and designing websites, Mitchell et al. (2011) explored the use of the Internet in assessing service provision for ageing people. Hollywood (2002) explained how and why Hanover redesigned their website to better suit senior Internet users and reviews some of the websites aimed at them. Raynes et al. (2004) found that the elderly currently do not view websites as a preferred source of information. The exploration suggests shaping a future in which websites are joined up and are informative for the elderly.

\section{Co-creation with the Elderly}

Co-creation is defined by Grönroos (2011: 291) as follows: "Firms when performing as service providers get opportunities to become co-creators of value with their customers, but only if direct interactions between service provider and customers exist." It means that "the provider participates as co-creator of value with the customer".

Commission of the European Communities (2007) emphasizes the role of the elderly people participating in society and the economy. Remaining active and thus empowered citizens and consumers is also important, thereby contributing to a positive perception of ageing in Europe. Little research has explored the possibilities of integrating older adults into a more active and influential role as customers (Kohlbacher and Herstatt 2008: xiii) or as participants developing new offerings (Essén and Östlund 2011, Wildevuur et al. 2013). In cases where services are specifically designed for the elderly, and even with their active participation, the focus has often been on supporting older adults in the challenges they are facing when getting older (e.g. Schmidt-Ruhland and Knigge 2008). A negative discourse constructs ageing as a challenge that needs to be treated by the society, not as an opportunity (Kohlbacher and Herstatt 2008). The results of de Blok et al.'s (2010) study showed that early client involvement allows for a combination of standard components that have a lower level of customization, 
whereas late client involvement allows for the adaptation of these components resulting in a higher level of customization.

Heikkilä et al. (1999) compared alternative service models for a grocery purchasing process as a part of home help for the elderly and disabled. The results indicated that using the electronic order delivery gives additional benefits, releasing the home-helper from the need to visit the grocery store. Tikkanen and Silvan (2012) described the service process of the home care catering comprising of an information system between the professional kitchen and the elderly. The role of the customers and their relatives was to provide input data into the system with respect to the needs and wants of an elderly. However, the main development need was concerned with an electronic information system. The theoretical framework for the paper is illustrated in Figure 2.

Figure 2. The Theoretical Framework for the Paper

\begin{tabular}{|c|}
\hline Constructivism Learning by Developing Action Model \\
\hline $\begin{array}{c}\text { Service Innovation \& Social Innovation: } \\
\text { Social Service Innovation }\end{array}$ \\
\hline Co-creating with the Elderly \\
\hline \\
\hline
\end{tabular}

\section{The Aim of the Paper}

The aim of this paper is to describe, how a digital service concept in wellbeing for the elderly was co-created as a process and a content in higher education. The co-creation was implemented by the students, teachers, and the elderly as a multidisciplinary team project within the curriculum. The case of www.seniori365 is introduced. Benefits for the elderly, relatives, firms, and for the City of Espoo are illustrated. Moreover, the project was evaluated by the students from the viewpoint of learning and competence development.

The paper is descriptive and the viewpoint is that of a university of applied sciences. This paper adds to the existing knowledge by describing a case of a social service innovations for the elderly in the practical context of teaching and learning.

\section{Methodology}

Work conducted towards the www.seniori365.fi digital service concept in wellbeing started in the autumn of 2013 and ended at the end of April in 2015. The ideas for the development of the service concept included the potential benefits in the "Wellbeing for the Elderly" project of the City of Espoo. The project inspired 
the project team to think what kinds of privately produced services the elderly need in the City of Espoo. Different kinds of innovation models and methods by Moritz (2005) and van Wulfen (2011) were utilized in the development process. The utilized methods are listed in Table 1. The core idea in developing the service concept entailed utilizing digitalization (Lyytikäinen \& Niskala 2015).

\section{Project Resources in www.seniori365.fi}

The role of the teachers in www.seniori365.fi was to present an authentic problem and a learning task to the students and control the schedule within the course assignment. One of the authors was a member of the service development project www.seniori365.fi. The student resources comprised of 44 students representing the Laurea University of Applied Sciences and three students representing the Helsinki Metropolia University of Applied Sciences, the total number of students being 47. The size of the project team amounted to 16 students (of whom 13 students studied on the Degree Programme in Business Management, and three students in the Degree Programme in Business Information Technology). Furthermore, eight students were project workers in the project and received salary for a part-time work. Moreover, 16 students (representing five degree programmes) participated in the course of Creating Innovation through Service Design and seven students (from the Degree Programmes in Business Management and Business Information Technology) wrote their Bachelor's theses on the topic. The third year students represented the Degree Programme in Business Information Technology (nine students), Business Management had 22 students, there were four nursing students, and eight students from Hotel and Restaurant Management. There was also one student in Security Management. Three students from the Helsinki Metropolia University of Applied Sciences represented the Degree Programme in Industrial Management.

The InnoEspoo project and its subproject seniori365.fi are innovation projects. The research design of those projects did not require the ethical approval from the financiers of the project and project partners because the data collection did not include any methods causing physical, psychic or legal protection harm. Moreover, the authors declare no conflict of interest.

\section{Project Results}

The project results comprise a description of co-creating a digital service concept in wellbeing as a process and a content of the concept. Also the following aspects are included: collected credits; written Bachelor's theses, and other learning tasks. Related aspects include benefits for the elderly, relatives, firms, and the City of Espoo. Finally, the co-creation process was evaluated by the students from the viewpoint of learning and competence development. 


\section{Co-creation of a Digital Service Concept in Wellbeing as a Process}

The co-creation process of a digital service concept in wellbeing is introduced in Table 1. The process comprised seven phases. In the first phase, the phenomenon of ageing was explored and the data were collected by the student team and the elderly by utilizing different kinds of data collection and idea creation methods. In the second phase, the collected data from the first phase was utilized when creating five themes based on the elderly's needs, wants etc. Moreover, twelve user profiles were designed by the student team. In the third phase, existing research was analysed and utilized in order to gain a deeper understanding for the development phase. In the fourth phase, development phase, different kinds of drafts for the service concept were created and a visual concept plan and a plan to proceed were made. A first draft for the digital service concept was created by the student team and the technical team. In the fifth phase, namely implementing the technical Internet service concept, technical aspects of the service concept were selected: content and its characteristics, platforms, servers, colours, structures, modules etc. and testing. This phase was implemented by the student team responsible for implementation. The elderly participated in testing the concept on the Internet. The sixth phase, content production and marketing, concentrated on creating the sales and registration processes, selecting the content for the service concept and searching for suitable firms for service providers. The seventh phase (launching the service concept) concentrated on communication by utilizing social media, holding events in various place and contacting organisations for the elderly (Himanen and Sahramaa 2015).

The project www.seniori365.fi is continuously operating as a learning environment for the students representing different degree programmes. The students take care of the technical maintenance, produce content materials for the web pages, obtain new firms for service providers, and market the services for the elderly and their relatives, to the actors, experts and organisations in the region of the City of Espoo (Seniori365.fi 2015).

\section{Collected Credits, Written Theses, and Learning Tasks}

The total number of collected credits from the project included about 500 credits (One credit corresponds from 25 to 30 hours of work; European Communities 2009: 11). So far, five Bachelor's theses have been published (seven students). The students collected data for their Bachelor's theses by participating in the project work and by interviewing the various actors in the project. Moreover, 240 service and product providers have registered into the service concept. One hundred and sixty service concept presentation visits have been conducted during September 15, 2014 and April 30, 2015. The number of visitors to the www.seniori365.fi pages is about 2,000 (Lyytikäinen \& Niskala 2015). 
Table 1. The Co-creation of a Digital Service Concept in Wellbeing as a Process

\begin{tabular}{|c|c|c|c|c|}
\hline Phase of the process & Collected data & Methods & Results & Co-creators \\
\hline 1. Under-standing & $\begin{array}{l}\text { - ageing } \\
\text { - digital services } \\
\text { - existing service concepts, service providers } \\
\text { - existing internet services for the elderly } \\
\text { - needs, feelings, worries of the elderly in a target } \\
\text { group }\end{array}$ & $\begin{array}{l}\text { - workshops } \\
\text { - benchmarking } \\
\text { - searching the internet } \\
\text { - interviewing the elderly } \\
\text { - data collected from senior } \\
\quad \text { workshops and events } \\
\end{array}$ & $\begin{array}{l}\text { - data for ideation } \\
\text { - report } \\
\text { - "weekdays of the elderly" }\end{array}$ & $\begin{array}{l}\text { - student team } \\
\text { - elderly }\end{array}$ \\
\hline 2. Thinking & - utilizing data from the "understanding" phase & $\begin{array}{l}\text { - 6-3-5 brainwriting technique } \\
\text { - two student teams and a teacher } \\
\text { - interviewing the elderly and their } \\
\text { carers in their different kinds of } \\
\text { life situations } \\
\text { - analysis of the created user } \\
\text { profiles }\end{array}$ & $\begin{array}{l}\text { - grouping the collected data } \\
\text { into five themes: activity } \\
\text { level; loneliness; nutrition; } \\
\text { security; and maintaining } \\
\text { health and wellbeing } \\
\text { - } 12 \text { user profiles were } \\
\text { created }\end{array}$ & $\begin{array}{l}\text { - student team } \\
\text { - elderly } \\
\text { - carers }\end{array}$ \\
\hline 3. Sort and explain & - utilizing existing research & - analysis of the results & & - student team \\
\hline 4. Development phase & $\begin{array}{l}\text { - different kinds of concepts for services were } \\
\text { created }\end{array}$ & $\begin{array}{l}\text { - ideation in meetings and } \\
\text { workshops }\end{array}$ & $\begin{array}{l}\text { - a visual concept plan } \\
\text { - to proceed } \\
\text { - first draft ready including } \\
\text { technical and content plan } \\
\text { - the best ideas for the } \\
\text { development were selected }\end{array}$ & $\begin{array}{l}\text { - student team } \\
\text { - student and technical team: busines } \\
\text { information technology }\end{array}$ \\
\hline $\begin{array}{ll}\text { 5. } & \text { Implementing } \\
\text { technical Internet } \\
\text { service concept }\end{array}$ & $\begin{array}{l}\text { - ideation and planning the content and its } \\
\text { characteristics } \\
\text { - testing different kinds of platforms } \\
\text { - selecting the server and other } \\
\text { - colours and structures, modules } \\
\text { - testing the concept } \\
\end{array}$ & $\begin{array}{l}\text { - searching both public and private } \\
\text { service providers }\end{array}$ & & $\begin{array}{l}\text { - student team responsible for } \\
\text { technical implementation ( } 7 \\
\text { students) } \\
\text { - elderly participated the testing the } \\
\text { concept on the internet }\end{array}$ \\
\hline $\begin{array}{l}\text { 6. } \begin{array}{l}\text { Content } \\
\text { production and } \\
\text { marketing }\end{array} \\
\text { mark }\end{array}$ & $\begin{array}{l}\text { - creating a sales process } \\
\text { - the registering process and tools } \\
\text { - selecting the content for the service concept and } \\
\text { updating it } \\
\text { - searching for suitable firms for service providers } \\
\text { - contacting firms by phone and e-mail }\end{array}$ & - brainstorming & $\begin{array}{l}\text { - excel table including firms } \\
\text { and their contact } \\
\text { information }\end{array}$ & - student team \\
\hline $\begin{array}{l}\text { 7. Launching the } \\
\text { service concept }\end{array}$ & $\begin{array}{l}\text { - utilizing social media in communication } \\
\text { - communicating about the service concept in } \\
\text { events, seminars and health care centres, service } \\
\text { homes and free time centres, the elderly's } \\
\text { organisations } \\
\text { - the service concept is further developed based on } \\
\text { usability tests }\end{array}$ & & & $\begin{array}{l}\text { - student team } \\
\text { - students of Omnia } \\
\text { - elderly }\end{array}$ \\
\hline
\end{tabular}

Source: Himanen and Sahramaa (2015). 


\section{Description of the www.seniori365.fi Digital Service Concept in Wellbeing}

The service concept in wellbeing was published in August 29, 2014 (Aalto University 2015) ${ }^{1}$. In order to maintain wellbeing, the elderly need services provided at homes, for example, cleaning services, repair and maintenance services, food services, IT services, healthcare services and tools for daily life. The co-created digital service concept in the field of wellbeing includes information about different kinds of products and services targeted to the elderly. Also other forms of information are included, such as activities, general information, information for carers and firms, and links to different organisations (Table 2).

In March 2015, www.seniori365.fi was awarded Good Practice 2014 service innovation by the Design for All Foundation (Seniori365.fi 2015, Design for All Foundation 2015) in the category of Spaces, products and services already in use. Furthermore, in October 2015, www.seniori365.fi was awarded EUWIIN women inventors' innovation competition in the category of Social Innovation \& Capacity Building (EUWIIN 2016), and Japan's IAUD Gold Award in the category of Co-Design (IAUD 2016).

\section{Benefits for the Elderly, Relatives, Firms, and the City of Espoo}

The elderly, their relatives, service providers (both in public and private sector) and students meet on the pages of www.seniori365.fi. For the elderly, the provided services in the City of Espoo are easy to find at www.seniori365.fi. Moreover, the provided services ease their daily life. However, if an elderly person, or a relative does not have an Internet access, the provided services have to be searched from other sources. For the elderly's relatives and careers, the provided services, service providers and their contact information are easy to find. The service providers have gained experience of services for the elderly and they know the elderly as a customer group (Lyytikäinen \& Niskala 2015).

For the firms, they have a possibility to gain new customers, to increase turnover and income, to establish new firms and offer their products and services for the elderly at their homes, forming a new customer group. For the students, the digital service concept provides possibilities to establish new ventures in the form of cooperatives, more job placements and possibilities for learning. For the City of Espoo, it may decrease its costs when the elderly utilize private services at their own expense (Lyytikäinen \& Niskala 2015).

\footnotetext{
${ }^{1}$ See: goo.gl/0EPEmR.
} 
Table 2. www.seniori365.fi Digital Service Concept in Wellbeing

\begin{tabular}{|c|c|c|c|c|c|c|}
\hline Services & Products & Activities & $\begin{array}{l}\text { General } \\
\text { information }\end{array}$ & For carers & For firms & Links \\
\hline $\begin{array}{l}\text { Beauty and } \\
\text { wellbeing } \\
\text { services }\end{array}$ & $\begin{array}{l}\text { Tools for } \\
\text { daily life }\end{array}$ & $\begin{array}{l}\text { Games and } \\
\text { tests }\end{array}$ & $\begin{array}{l}\text { Services for } \\
\text { daily life }\end{array}$ & $\begin{array}{l}\text { Information } \\
\text { for carers }\end{array}$ & $\begin{array}{l}\text { Information } \\
\text { for firms }\end{array}$ & $\begin{array}{l}\text { Links to the } \\
\text { City of Espoo } \\
\text { and its } \\
\text { organisations }\end{array}$ \\
\hline $\begin{array}{l}\text { House- } \\
\text { keeping and } \\
\text { repairing } \\
\text { services }\end{array}$ & $\begin{array}{l}\text { Wellbeing } \\
\text { products }\end{array}$ & Videos & $\begin{array}{l}\text { Tourism } \\
\text { services }\end{array}$ & & $\begin{array}{l}\text { Registration } \\
\text { for the } \\
\text { service }\end{array}$ & $\begin{array}{l}\text { Links to } \\
\text { public services }\end{array}$ \\
\hline $\begin{array}{l}\text { Health care } \\
\text { services }\end{array}$ & $\begin{array}{l}\text { Wellbeing } \\
\text { technology }\end{array}$ & Media & $\begin{array}{l}\text { Health and } \\
\text { wellbeing }\end{array}$ & & & \begin{tabular}{|l|} 
Links to \\
various \\
organisations
\end{tabular} \\
\hline $\begin{array}{l}\text { Exercise } \\
\text { services }\end{array}$ & \begin{tabular}{|l|} 
Maintaining \\
functional \\
ability
\end{tabular} & Discussion & $\begin{array}{l}\text { Activities } \\
\text { for the } \\
\text { elderly }\end{array}$ & & & \\
\hline $\begin{array}{l}\text { Nutrition } \\
\text { and food } \\
\text { services }\end{array}$ & \begin{tabular}{|l|} 
Safety and \\
security \\
products
\end{tabular} & Food recipes & & & & \\
\hline $\begin{array}{l}\text { Home care } \\
\text { and help in } \\
\text { daily } \\
\text { matters }\end{array}$ & $\begin{array}{l}\text { E-commerce } \\
\text { services }\end{array}$ & $\begin{array}{l}\begin{array}{l}\text { Event } \\
\text { calendar }\end{array} \\
\end{array}$ & & & & \\
\hline $\begin{array}{l}\text { Information } \\
\text { technology } \\
\text { services }\end{array}$ & & $\begin{array}{l}\text { Equipment } \\
\text { presentation }\end{array}$ & & & & \\
\hline $\begin{array}{l}\text { Other } \\
\text { services }\end{array}$ & & Remembrance & & & & \\
\hline \multicolumn{7}{|c|}{ Value proposition: Wellbeing for the whole year } \\
\hline
\end{tabular}

Source: www.seniori365.fi.

Evaluating the Co-creation by the Project Students from the Viewpoint of Learning and Competence Development

Forty-seven students representing seven degree programmes participated in www.seniori365.fi concept project (including content planning, technical planning and implementation, and maintaining the concept on the Internet). The project provided the students with excellent possibilities for learning and for competence development in the form of theses, practical training and project studies. These kinds of projects offer the students the possibility to participate in the real-life projects, where they can apply their knowledge and competences, and where their competences are further developed (Lyytikäinen \& Niskala 2015).

In their evaluation the students perceived the following topics to be the most educational: the needs and wishes of the elderly; electronic marketing; working in a multidisciplinary group; developing a new service; meeting capable nice people; and learning self-confidence. Some of the students' authentic comments are below (Lyytikäinen \& Niskala 2015). 
"The most challenging thing in the project was to discern the needs and wishes of the target group, that is to say, the elderly. A lot of time was allocated to creating the user interface and visual image in order that the web page would suit all users. The team got valuable feedback from the elderly during the project." (The student team)

"It has been brilliant to participate in the project from the beginning and see how the web page has been created from zero to the current form. The project has raised my interest in electronic marketing and advertising. I have had experience in presentation especially, when marketing the service to the elderly and when acting in a multidisciplinary team." (A student of Business Management)

"It has been brilliant in the project to develop a new and a necessary service from the beginning as a part of a multidisciplinary team. The project has also been very useful from the viewpoint of my own competences, because in the project I have cumulated a lot of experience of the planning and implementation of a system interface. Of course, during the project I have had an excellent opportunity to become familiar with many capable and nice people!" (A student of Business Information Technology)

"The role of a project manager has given me self-confidence to make decisions and the possibility to work as a manager of a very colourful and big team. So, believe it or not, this team has not been the easiest group to tend. This kind of responsibility has developed and educated me as a person and as a team manager. So it has felt my own and a good thing. I have had an unbelievably good experience of marketing a digital service for the end users, selling the service to potential service providers and also planning the service content for the target group." (Project manager, a student of Business Management)

Evaluating the Co-created www.seniori365.fi Digital Service Concept by the Project Students

An evaluation of the co-created wellbeing digital service concept was conducted from the viewpoints of four areas (Nylén \& Holmström 2015). User experience was implemented in www.seniori365.fi service concept among the elderly in four phases: understanding, thinking, implementing the technical Internet service concept, and implementing the service concept with respect to testing (Table 1). A value proposition was created, "Wellbeing for the whole year", illustrating the content of the service concept. As for the digital evolution scanning, the current service concept is only available via a computer, not on a mobile phone. New skills, competences and learning were achieved through the development process when the students worked in teams in various roles. The student team was a multidisciplinary team. The students of Business Information 
Technology concentrated on planning and implementing the Internet solutions for the service concept. Time for improvisation was allocated, especially in the first two phases of the development process. However, creating ideas and coordination were carried out throughout the development process.

\section{Conclusions}

The digital service concept in wellbeing for the elderly and their relatives was co-created by the students, teachers, and the elderly. Forty-seven students, representing seven disciplines at a university of applied sciences, were responsible for the data collection from the elderly, ideation, concept innovation, contents of the concept, promotion, publicity, technical electronic infrastructure, graphics, pictures, contacts to service providers etc. The cocreation of the service concept was a part of their curriculum in multiple ways: it involved learning tasks, writing Bachelor's theses, course assignments, job placements, providing project work with salary etc. The total number of collected credits amounted to about 500 credits.

The digital service concept in wellbeing was implemented by following the LbD action model, namely the pedagogical model of the Laurea University of Applied Sciences. The LbD action model is based on constructivism. The implemented project was a real-life authentic project where the set problem was solved successfully. Furthermore, the www.seniori365.fi concept has got three international awards (Design for All Foundation 2015, EUWIIN 2016, IAUD 2016). The created service concept benefited students, the elderly, their relatives, the local entrepreneurs, the City of Espoo, and the financiers. The students received good practice when working in a multidisciplinary team with various opinions, competences, theoretical backgrounds and they solved the set problem successfully.

The achieved results illustrate an example how the digital service concept in wellbeing was co-created by the student in a multidisciplinary team, teachers, and the elderly based on the constructivism included in the curriculum. The results also describe the cooperation between the students, the teachers, and the elderly from the pedagogical viewpoint.

The www.seniori365.fi digital service concept as a social service innovation is ready to be disseminated outside the City of Espoo - even to international markets. Also, the elderly in other municipalities and regions could benefit from the similar service. The kind of a content that could be developed is only a question of ideation and innovation (Lyytikäinen \& Niskala 2015). The project results may interest an international audience as an example of a social innovations in the curriculum and LbD action model. 


\section{References}

Blake M (1998) Internet access for older people. Aslib Proceedings 50(10): 308-315.

Brown TH (2006) Beyond constructivism: navigationism in the knowledge era. On the Horizon 3: 108-120.

Commission of the European Communities (2007) Ageing well in the information society. An 2010 initiative action plan on information and communication technologies and ageing [COM(2007)332], Brussels, 14 June 2007. Retrieved from goo.gl/4MRVMI

Cooperstein SE, Kocevar-Weidinger E (2004) Beyond active learning: a constructivist approach to learning. Reference Services Review 32(2): 141-148.

de Blok C, Luijkx K, Meijboom B, Schols J (2010) Modular care and service packages for independently living elderly. International Journal of Operations \& Production Management 30(1): 75-97.

Design for All Foundation (2015) Good Practices recognized by Design for All Foundation. Retrieved from goo.gl/81PBO5

Duncan AK, Breslin MA (2009) Innovating health care delivery: the design of health services. Journal of Business Strategy 30(2/3): 13-20.

Eastman JK, Iyer R (2004) The elderly's uses and attitudes towards the Internet. Journal of Consumer Marketing 21(3): 208-220.

Espoo (2015) InnoEspoo-osaajaverkostoa rakennetaan (InnoEspoo-expert network will be built). Retrieved from goo.gl/TW23Cu.

Essén A, Östlund B (2011) Laggards as Innovators? Old Users as Designers of New Services \& Service Systems. International Journal of Design 5(3): 89-98.

European Commission (2015) Social Innovation Europe. Retrieved from goo.gl/1UUa0h.

European Communities (2009) ECTS Users' Guide. Education and Culture DG. Retrieved from goo.gl/7GxhM4.

EUWIIN (2016) $5^{\text {th }}$ Bi-Annual International European Women Inventors \& Innovators Network Exhibition, Conference \& Awards Ceremony, Awardees. Retrieved from goo.gl/MvZ7rY.

Giannopoulou E, Gryszkiewicz L, Barlatier P-J (2014) Creativity for service innovation: a practice-based perspective. Managing Service Quality: An International Journal 24(1): 23-44.

Good TL, Brophy JE (1994) Looking in Classrooms. New York, NY: HarperCollins College Publishers.

Grönroos C (2011) Value co-creation in service logic: A critical analysis. Marketing Theory 11(3): 279-301.

Heikkilä J, Kallio J, Saarinen T, Tuunainen VK (1999) EC of groceries for elderly and disabled: A comparison of alternative service models. Information Technology \& People 12(4): 389-402.

Helsper E (2009) The ageing internet: digital choice and exclusion among the elderly. Working with Older People 13(4): 28-33.

Hennala L, Parjanen S, Uotila T (2011) Challenges of multi-actor involvement in the public sector front-end innovation processes: Constructing an open innovation model for developing well-being services. European Journal of Innovation Management 14(3): 364-387.

Hill R, Beynon-Davies P, Williams MD (2008) Older people and internet engagement: Acknowledging social moderators of internet adoption, access and use. Information Technology \& People 21(3): 244-266. 
Himanen L, Sahramaa N (2015) Adventure of innovation process. Case InnoEspoo Project. Bachelor's thesis. Laurea University of Applied Sciences (in Finnish). Retrieved from goo.gl/ttwTfy.

Hollywood M (2002) Designing websites aimed at older people. Working with Older People 6(1): 35-37.

Hsieh J-K, Chiu H-C, Wei C-P, Yen HR, Chen Y-C (2013) A practical perspective on the classification of service innovations. Journal of Services Marketing 27(5): 371-384.

IAUD (2016) Announcement of IAUD Award 2015 Winners. Retrieved from goo.gl/jr UOVs.

INNOVAGE (2014) Guidelines on involving older people in social innovation development, Age Platform Europe. Retrieved from goo.gl/B0WoAE

Kallioinen O (Ed.) (2008) Oppiminen Learning by Developing -toimintamallissa (Learning in the Learning by Developing Model). Helsinki: Laurea Publications A-61.

Kohlbacher F, Herstatt C (Eds.) (2008) The silver market phenomenon: Business opportunities in an era of demographic change. Berlin, DE: Springer.

Lehto P, Leskelä J (Eds.) (2011) Interaktiivinen hyvinvointiTV and käyttäjälähtöiset ePalvelut (Interactive Caring and user-oriented e-Services). Safe Home Project Final Report. Laurea University of Applied Sciences, Publications B44. Retrieved from goo.gl/CcRjzS.

Lyytikäinen J, Niskala K (Eds.) (2015) InnoEspoo: Avaus uuteen yli rajojen (InnoEspoo: Open a new cross-border). Vantaa: Multiprint Oy. Retrieved from goo.gl/cC75Wf.

Mitchell CP, Morgan G, Gallaher J (2011) Use of the internet in assessing service provision for older people. Quality in Ageing and Older Adults 12(4): 234-238.

Moritz S (2005) Service design - practical access to an evolving field. Cologne, Germany: Köln International School of Design.

Nuthall G (2002) Social constructivist teaching and the shaping of students' knowledge and thinking. In J Brophy (eds.), Social Constructivist Teaching: Affordances and Constraints (Advances in Research on Teaching, Vol. 9) (pp. 4379). Emerald Group Publishing Limited.

Nylén D, Holmström J (2015) Digital innovation strategy: A framework for diagnosing and improving digital product and service innovation. Business Horizons (January-February): 57-67.

Porcaro D (2011) Applying constructivism in instructivist learning cultures. Multicultural Education \& Technology Journal 5(1): 39-54.

Raij K (Eds.) (2014) Learning by Developing Action Model. Laurea University of Applied Sciences, Laurea Publications 36. Retrieved from goo.gl/QWj50s.

Raynes N, Pagidas D, Margiotta P, Lawson J (2004) Information for older people: The contribution of local authority websites. Journal of Integrated Care 12(4): 35-41.

Reisenwitz T, Iyer R, Kuhlmeier DB, Eastman JK (2007) The elderly's internet usage: an updated look. Journal of Consumer Marketing 24(7): 406-418.

Schmidt-Ruhland K, Knigge M (2008) Integration of the elderly in the design process. In F Kohlbacher, C Herstatt (Eds.), The Silver Market Phenomenon. Business Opportunities in an Era of demographic change (pp. 103-124). Berlin, DE: Springer.

Seniori365.fi (2015) Hyvinvointia koko vuodeksi (Wellbeing for the whole year). Retrieved from http://www.seniori365.fi/

Soma P, Reynold J (2014) The pains and gains of blended learning - social constructivist perspectives. Education + Training 56(4): 254-270. 
SSIA (2015) Passion for Life. Social Services Improvement Agency. Retrieved from goo.gl/E1yZGs.

Statistics Finland (2015) PX-Web-data base. Retrieved from goo.gl/IWs2wL.

Statistics Finland (2016) Internetin käyttö mobiilia, laitteet henkilökohtaisia (Internet use in mobile, personal equipment). Retrieved from: goo.gl/buB3xR.

Tatnall A, Lepa J (2003) The Internet, e-commerce and older people: an actor-network approach to researching reasons for adoption and use. Logistics Information Management 16(1): 56-63.

The Helsinki Metropolitan Area Advisory Board (2007) Pääkaupunkiseudun väestöja palvelutarveselvitys 2015 ja 2025. Kunta- ja palvelurakenneuudistushanke 19.6.2007 (The metropolitan area of population and service needs statement 2015 and 2025. The municipal and service structure project 19.6.2007) Retrieved from goo.gl/cI2Yve.

Tikkanen I, Silvan A (2012) Developing the service process of municipal home care catering. Nutrition \& Food Science 42(5): 315-323.

Tikkanen I, Vakkuri M (2013) Developing a teaching restaurant as an R\&D\&I environment. Higher Education, Skills and Work-based Learning 3(3): 207-218.

Trocchia PJ, Janda S (2000) A phenomenological investigation of Internet usage among older individuals. Journal of Consumer Marketing 17(7): 605-616.

UniCredit Foundation (2015) Social Innovation in Ageing - The European Award. Retrieved from goo.gl/DUQZ8I.

van Wulfen G (2011) Creating Innovative Products and Services. The Forth Innovation method._Burlington, VT: Gower Pub. Ltd.

Vuori S, Holmlund-Rytkönen M (2005) 55+ people as internet users. Marketing Intelligence \& Planning 23(1): 58-76.

Wang Q, Voss C, Zhao X, Wang Z (2015) Modes of service innovation: a typology. Industrial Management \& Data Systems 115(7): 1358-1382.

Wildevuur S, van Dijk D, Äyväri A, Bjerre M, Hammer-Jakobsen T, Lund J (2013) Connect: Design for an empathic society. Amsterdam: BIS Publishers. 
